\title{
POLA KONSUMSI PANGAN, AKTIVITAS FISIK, RIWAYAT PENYAKIT, RIWAYAT DEMENSIA KELUARGA, DAN KEJADIAN DEMENSIA PADA LANSIA DI PANTI WERDHA TRESNA BOGOR
}

\author{
(Food Consumption Patterns, Physical Activity, History of the Disease, Family History of Dementia, \\ and Incidence of Dementia in Elderly in Tresna Werdha Nursing, Bogor)
}

Chairunnisa Utami Pratiwi ${ }^{1 *}$, Sri Anna Marliyati ${ }^{1}$, dan Melly Latifah²

\begin{abstract}
1Departemen Gizi Masyarakat, Fakultas Ekologi Manusia (FEMA), Institut Pertanian Bogor, Bogor 16680
2Departemen Ilmu Keluarga dan Konsumen, Fakultas Ekologi Manusia (FEMA), Institut Pertanian Bogor, Bogor 16680
\end{abstract}

\begin{abstract}
The objective of this study were to analyze the patterns of food consumption, physical activity, history of disease, family history of dementia, and incidence of dementia in elderly in Werdha Tresna, nursing home, Bogor. Research design was cross sectional study with 42 elderly as subjects. The results showed that there were significant correlation between the level of education, adequacy of level vitamin A, vitamin B1, vitamin B2, vitamin B6, vitamin C, history of diabetes and physical activity with incidence of dementia in elderly $(p<0.05)$. There were no significant correlation between age, adequacy of level folic acid, history of hypertension, and family history of dementia with incidence of dementia in elderly ( $p>0.05)$.
\end{abstract}

Keywords: cognitive, dementia, memory, patterns of consumption, physical activity

\begin{abstract}
ABSTRAK
Penelitian ini bertujuan untuk menganalisis pola konsumsi pangan, aktivitas fisik, riwayat penyakit, riwayat demensia keluarga, dan kejadian demensia pada lansia di Panti Werdha Tresna, Bogor. Desain penelitian ini adalah cross sectional dengan subjek penelitian sebanyak 42 lansia. Hasil penelitian menunjukkan bahwa terdapat hubungan yang signifikan antara tingkat pendidikan, tingkat kecukupan vitamin A, vitamin B1, vitamin B2, vitamin B6, vitamin C, riwayat penyakit diabetes mellitus, dan aktivitas fisik dengan kejadian demensia pada lansia $(\mathrm{p}<0.05)$. Tidak terdapat hubungan yang signifikan antara usia, tingkat kecukupan asam folat, riwayat hipertensi, dan riwayat demensia keluarga dengan kejadian demensia pada lansia $(p>0.05)$.
\end{abstract}

Kata kunci: aktivitas fisik, demensia, kognitif, memori, pola konsumsi

"Korespondensi: Departemen Gizi Masyarakat, Fakultas Ekologi Manusia (FEMA), Institut Pertanian Bogor, Bogor 16680. Email: nizza_22@rocketmail.com 
Pratiwi dkk.

\section{PENDAHULUAN}

Menurut Undang-Undang Republik Indonesia nomor 13 tahun 1998 tentang kesejahteraan lanjut usia (pasal 1 ayat 2), lanjut usia adalah seseorang yang telah mencapai usia 60 tahun ke atas. Di Indonesia sendiri pada tahun 2000, jumlah lansia me-ningkat mencapai $9.99 \%$ dari seluruh penduduk Indonesia dengan usia harapan hidup 65-70 tahun. Pada tahun 2020 diperkirakan akan mencapai 30 juta orang dengan usia harapan hidup 70-75 tahun.

Peningkatan usia harapan hidup di Indonesia akan meningkatkan jumlah penduduk usia lanjut. Perlu diwaspadai adanya peningkatan penyakit yang berhubungan dengan proses degeneratif, diantaranya demensia, yang gejalanya berupa ketidakmampuan untuk hidup mandiri dan akan menjadi beban keluarga, masyarakat dan negara. Demensia merupakan kumpulan gejala klinik yang disebabkan oleh berbagai latar belakang penyakit dan ditandai oleh hilangnya memori jangka pendek, gangguan global fungsi mental (termasuk fungsi bahasa), mundurnya kemampuan berpikir abstrak, kesulitan merawat diri sendiri, perubahan perilaku, emosi labil, dan hilangnya pengenalan waktu dan tempat. Proses penuaan otak abnormal merupakan bagian dari proses degenerasi pada seluruh organ tubuh. Hal ini akan menimbulkan berbagai gangguan neuropsikologis dan masalah yang terbesar adalah demensia.

Gray et al. (2008) menyebutkan bahwa demensia bukanlah sekedar penyakit biasa, melainkan kumpulan gejala yang disebabkan beberapa penyakit atau kondisi tertentu sehingga terjadi perubahan kepribadian dan tingkah laku. Demensia sangat berkaitan dengan lanjut usia. Menurut Richard et al. (2007), kejadian demensia berkaitan dengan dua faktor, yaitu protective factors dan risk factors. Protective factors terdiri dari tingkat pendidikan, aktivitas fisik, dan pola konsumsi. Pola makan yang baik dan beraneka ragam dapat memperbaiki mutu gizi makanan seseorang (Slamet 2009). Zat gizi mikro diketahui berkaitan dengan kejadian demensia pada lansia, terutama vitamin B kompleks. Kekurangan vitamin B kompleks pada lansia dapat meningkatkan risiko terjadinya demensia. Risk factors terdiri dari usia, riwayat penyakit, dan riwayat demensia keluarga. Tujuan penelitian ini adalah menganalisis pola konsumsi pangan, aktivitas fisik, riwayat penyakit, riwayat demensia keluarga, dan kejadian demensia pada lansia.

\section{METODE}

\section{Desain, Tempat, dan Waktu}

Penelitian ini menggunakan desain Cross Sectional yang dilaksanakan di Panti Werdha Tresna, Bogor pada bulan Maret-Mei 2013. Pemilihan tempat dilakukan secara purposive.

\section{Jumlah dan Cara Penarikan Subjek}

Subjek dalam penelitian ini adalah seluruh lansia yang tinggal di Panti Werdha Tresna, Bogor atau sejumlah 42 orang. Lansia yang tinggal di panti, seluruhnya berjenis kelamin perempuan. Subjek harus memiliki kriteria sebagai berikut: bersedia untuk menjadi subjek penelitian, sehat, dan memiliki tingkat kesadaran yang masih baik. Subjek yang sudah tidak dapat berkomunikasi dengan baik dan memiliki gangguan pendengaran tidak dimasukkan dalam penelitian.

\section{Jenis dan Cara Pengumpulan Data}

Data primer meliputi karakteristik subjek, pola konsumsi pangan, status gizi, aktivitas fisik, riwayat penyakit, riwayat demensia keluarga, dan keadaan kognitif subjek. Data sekunder meliputi data gambaran umum dan jadwal kegiatan panti. Pengumpulan data dilakukan dengan wawancara secara langsung dengan kuesioner, pengukuran langsung, dan penggunaan data kesehatan dari pihak panti Werdha Tresna.

\section{Pengolahan dan Analisis Data}

Analisis yang digunakan dalam penelitian ini adalah analisis deskriptif dan inferensia. Analisis deskriptif digunakan untuk menggambarkan karakteristik subjek, kebiasaan makan, frekuensi konsumsi makan, tingkat kecukupan gizi, aktivitas fisik, status gizi, riwayat penyakit, riwayat demensia keluarga subjek, dan kondisi kognitif untuk melihat risiko kejadian demensia pada subjek. Penelitian ini menggunakan metode semi kuantitatif untuk mengetahui frekuensi makan dan kebiasaan makan subjek dengan wawancara menggunakan Food Frequency Questionnaires (FFQ). Metode kuantitatif recall $2 \times 24$ jam digunakan untuk mengetahui konsumsi pangan subjek.

Clinical Dementia Rating Scale (CDR) didesain untuk mengukur demensia yang berkelanjutan. CDR menggambarkan lima tingkatan demensia dalam enam faktor yaitu daya ingat, orientasi, penilaian dan pemecahan masalah, kehidupan bermasyarakat, hobi dan rumah tangga, dan perawatan diri. Masingmasing dari tingkatan demensia memiliki skor 0; 0.5; 1; 2; dan 3. Skor 0 (healthy) berarti subjek masih sehat. Skor 0.5 (questionable dementia) merujuk pada subjek dengan kerusakan kognitif namun belum demensia akan tetapi memiliki risiko tinggi untuk menjadi demensia di masa mendatang. Skor 1, 2, 3 merujuk pada subjek dengan demensia ringan (mild dementia), sedang (moderate dementia), dan berat (severe dementia) (OTA 1987).

Untuk memperhitungkan perbedaan dalam ukuran tubuh dan komposisi, energi dari kegiatan dihitung sebagai BMR per menit, juga disebut sebagai Physical Activity Ratio (PAR), dan energi dari kegiatan selama 24 jam ini dinyatakan sebagai BMR 
per 24 jam dengan menggunakan nilai PAL (Physical Activity Level) (FAO/WHO/UNU 2001). Nilai PAL dibagi menjadi 4 kelompok, yaitu $P A L \geq 1<1.4$ dikatakan sedentary atau tidak aktif, $P A L \geq 1.4<1.6$ dikatakan kurang aktif, PAL $\geq 1.6<1.9$ dikatakan aktif, dan $P A L \geq 1.9<2.5$ dikatakan sangat aktif.

Analisis inferensia digunakan untuk melihat hubungan antar variabel. Hubungan antara karakteristik lansia, tingkat kecukupan vitamin A, vitamin B1, vitamin B2, vitamin B6, asam folat, vitamin C, aktivitas fisik, riwayat penyakit, dan riwayat demensia keluarga dengan kejadian demensia dianalisis dengan uji korelasi Spearman. Faktor-faktor yang berpengaruh terhadap kejadian demensia pada lansia di Panti Werdha Tresna Bogor dianalisis dengan uji multiregresi logistik.

\section{HASIL DAN PEMBAHASAN}

\section{Karakteristik Subjek}

Subjek penelitian berjumlah 42 wanita lansia dengan kisaran usia antara 60 sampai 82 tahun. Berdasarkan pemeriksaan CDR, sebanyak $57.1 \%$ lansia mengalami demensia dan $42.9 \%$ lansia tidak mengalami demensia. Sebagian besar subjek demensia tidak sekolah (54.2\%) dan sebagian besar subjek tidak demensia merupakan tamatan Sekolah Dasar (33.3\%). Sebagian besar subjek telah menikah dengan jumlah keluarga tergolong kecil yaitu <4 orang.

\section{Pola Kosumsi Pangan}

Frekuensi makan. Berdasarkan hasil wawancara FFQ, subjek yang demensia dan tidak demensia mengonsumsi nasi sebanyak 20-21 kali/minggu atau 2-3 kali per hari. Pangan hewani yang paling sering dikonsumsi dari keseluruhan subjek adalah telur (5-6 kali seminggu). Selain telur, jenis pangan hewani yang sering dikonsumsi oleh subjek adalah daging ayam yaitu rata-rata 3-4 kali/minggu. Tahu dan tempe adalah pangan sumber protein nabati yang paling sering dikonsumsi oleh keseluruhan subjek. Rata-rata frekuensi konsumsi tahu dan tempe pada subjek yang demensia dan tidak demensia adalah sebanyak 8-9 dan 6-7 kali dalam seminggu. Pisang dan pepaya merupakan buah yang paling sering dikonsumsi subjek. Pisang dan pepaya rata-rata dikonsumsi 1-2 kali dalam seminggu. Wortel dan kol merupakan sayuran yang paling sering dikonsumsi subjek. Frekuensi konsumsi wortel dan kol pada subjek rata-rata $2-3$ kali dalam seminggu.

Kebiasaan makan. Sebagian besar subjek memiliki frekuensi makan 3 kali sehari. Sebagian besar subjek dari kedua kelompok selalu sarapan pagi, yaitu sebesar $80.0 \%$ untuk subjek yang demensia dan sebesar $83.3 \%$ untuk subjek yang tidak demensia. Waktu sarapan pagi biasanya pada pukul 05.30-06.30. Hal ini berkaitan dengan penyediaan sarapan oleh panti yang dilakukan sekitar pukul 06.00 pagi. Menu sarapan pagi biasanya berupa nasi dan lauk pauk. Keseluruhan subjek terbiasa untuk makan siang dan makan malam secara teratur.

Kebiasaan minum. Asupan air pada lansia harus lebih diperhatikan karena osmoreseptor kurang sensitif sehingga mereka kerap tidak merasa haus. Minuman yang biasa diminum subjek ketika pagi atau malam adalah teh manis dan air putih. Sebesar $66.7 \%$ subjek yang demensia biasa minum teh manis ketika pagi atau malam hari, dan sebesar $50 \%$ subjek yang tidak demensia biasa minum air putih ketika pagi atau malam hari. Konsumsi air putih rata-rata untuk subjek yang demensia sebagian besar adalah sebanyak 3 gelas sehari, dan 5-8 gelas sehari untuk subjek yang tidak demensia.

\section{Status Gizi}

Status gizi didefinisikan sebagai keadaan kesehatan tubuh seseorang atau kelompok orang yang diakibatkan oleh konsumsi, penyerapan (absorpsi), dan penggunaan (utilisasi) zat-zat gizi makanan (Hsu 2006). Batas ambang nilai IMT menurut Depkes (2005) untuk orang Indonesia adalah $<18.5 \mathrm{~kg} /$ $\mathrm{m}^{2}$ termasuk dalam kategori kurus, $18.5-25.0 \mathrm{~kg} /$ $\mathrm{m}^{2}$ untuk kategori normal, dan $>25 \mathrm{~kg} / \mathrm{m}^{2}$ untuk kategori gemuk. Hasil analisis status gizi menunjukkan sebanyak $62.3 \%$ subjek yang demensia memiliki status gizi normal dan 55.6\% untuk subjek yang tidak demensia.

\section{Tingkat Kecukupan Gizi}

Energi dibutuhkan untuk segala aktivitas yang dilakukan oleh tubuh, diantaranya untuk mempertahankan proses yang dilakukan oleh organ dalam, melaksanakan aktivitas luar, tumbuh, dan untuk menjaga agar tubuh tetap hangat. Kebutuhan akan kalori menurun seiring dengan pertambahan usia, karena metabolisme seluruh sel dan kegiatan otot berkurang (Arisman 2004).

Berdasarkan Angka Kecukupan Gizi (AKG) tahun 2004, diketahui angka kecukupan energi untuk wanita di atas 60 tahun adalah 1600 kkal. Ratarata AKG untuk energi yang telah dikonversi sesuai berat badan masing-masing subjek adalah sebesar 1321 kkal. Rata-rata asupan energi subjek yang demensia (1 $270 \mathrm{kkal}$ ) lebih rendah dibandingkan dengan subjek yang tidak demensia (1 546 kkal). Perbedaan rata-rata asupan adalah 300 kkal untuk energi. Meskipun terdapat perbedaan untuk asupan energi subjek yang demensia dan tidak demensia, rata-rata tingkat kecukupan energi dari kedua kelompok subjek tergolong cukup (100-119\% AKE).

Protein mempunyai fungsi utama untuk pertumbuhan dan pemeliharaan jaringan, pembentukan senyawa esensial, regulasi keseimbangan air, pembentukan antibodi, transportasi zat gizi, dan lain-lain. Rata-rata AKG untuk protein yang telah 
dikonversi sesuai berat badan masing-masing subjek adalah sebesar $40.4 \mathrm{~g}$. Rata-rata asupan protein subjek yang demensia (31.6 g) lebih rendah dibandingkan dengan subjek yang tidak demensia (41.4 g). Perbedaan rata-rata konsumsi adalah sekitar $10 \mathrm{~g}$ untuk protein. Perbedaan rata-rata asupan menyebabkan adanya perbedaan untuk tingkat kecukupan harian protein subjek. Rata-rata tingkat kecukupan protein untuk subjek yang demensia tergolong defisit ringan karena hanya memenuhi 80-89\% AKP, sedangkan untuk subjek yang tidak demensia tergolong normal karena sudah memenuhi sekitar 90-119\% AKP.

Vitamin A merupakan substansi yang tidak larut dalam air dan disimpan dalam tubuh terutama di hati yang kemudian dilepas dalam aliran darah untuk digunakan oleh seluruh sel epitel tubuh, termasuk mata dan sel-sel benih fosforeseptor mata (Arisman 2004). Seluruh subjek memiliki tingkat kecukupan vitamin A yang cukup ( $\geq 77 \%$ AKG). Tingkat kecukupan vitamin A yang cukup untuk kedua kelompok subjek berkaitan dengan rata-rata asupan vitamin A yang cukup.

Kekurangan vitamin B1 dapat ditandai dengan adanya penurunan nafsu makan, depresi mental, dan lemah. Defisiensi kronis vitamin B1 akan muncul gejala kelainan neurologis seperti kebingungan (mental) dan kehilangan koordinasi mata. Sebagian besar subjek dari kedua kelompok (demensia dan tidak demensia) memiliki tingkat kecukupan vitamin B1 yang tergolong defisit, yaitu $<77 \%$ AKG vitamin B1 harian. Hal ini berkaitan dengan rendahnya konsumsi bahan pangan yang banyak mengandung vitamin B1. Rata-rata asupan vitamin B1 untuk kedua kelompok subjek tergolong rendah, dimana hanya sekitar 0.46 mg untuk subjek yang tidak demensia dan sekitar $0.26 \mathrm{mg}$ untuk subjek yang demensia.

Vitamin B2 atau riboflavin merupakan komponen suatu enzim yang dikenal sebagai flavoprotein dan terlibat dalam reaksi metabolisme intermediet. Sebagian besar subjek dari kedua kelompok memiliki tingkat kecukupan vitamin B2 yang tergolong defisit, yaitu $<77 \%$ AKG vitamin B2 harian. Rata-rata asupan vitamin B2 untuk kedua kelompok subjek tergolong rendah, dimana hanya sekitar $0.54 \mathrm{mg}$ untuk subjek yang tidak demensia dan sekitar $0.32 \mathrm{mg}$ untuk subjek yang demensia.

Sumber utama vitamin B6 adalah daging, unggas, ikan, kentang, ubi jalar, sayur-sayuran, susu, dan biji-bijian. Kekurangan vitamin B6 menyebabkan gejala kulit rusak, syaraf motorik terganggu, dan kelainan darah. Subjek yang tidak demensia sebagian besar sudah memiliki tingkat kecukupan vitamin B6 yang cukup, yaitu $\geq 77 \%$ AKG vitamin B6 harian. Perbedaan tingkat kecukupan vitamin B6 pada kedua kelompok subjek berkaitan dengan perbedaan ratarata asupannya. Rata-rata asupan vitamin B6 untuk subjek yang tidak demensia sekitar $1.34 \mathrm{mg}$ dan sekitar $0.97 \mathrm{mg}$ untuk subjek yang demensia.
Asam folat mampu meningkatkan konsentrasi plasma docosahexaenoic acid (DHA) dan eicosapentaenoic acid (EPA). EPA, DHA, dan asam arakhidonat berperan dalam kejadian demensia dengan meregulasi kembali ekspresi gen yang berkaitan dengan neurogenesis, neurotransmisi, dan konektivitas. EPA, DHA, dan asam arakhidonat mampu meningkatkan asetilkolin di otak dan menghambat senyawa antiinflamasi yang melindungi neuron dari aktivitas sitotoksik berupa berbagai rangsangan stres oksidatif (Das 2008). Diketahui seluruh subjek dari kedua kelompok (demensia dan tidak demensia) memiliki tingkat kecukupan asam folat yang tergolong defisit, yaitu $<77 \%$ AKG asam folat harian.

Sebagian besar subjek yang demensia (66.7\%) memiliki tingkat kecukupan vitamin $C$ yang kurang (<77\% AKG) dan sebagian besar subjek yang tidak demensia (55.6\%) memiliki tingkat kecukupan vitamin C yang cukup (>77\% AKG). Hal ini berkaitan dengan perbedaan rata-rata konsumsi buah dan sayur subjek yang demensia dan subjek yang tidak demensia. Sayur dan buah merupakan sumber vitamin $C$ yang baik untuk dikonsumsi. Rata-rata asupan vitamin $\mathrm{C}$ untuk subjek yang tidak demensia sekitar $69.4 \mathrm{mg}$ dan sekitar $52.2 \mathrm{mg}$ untuk subjek yang demensia.

Fosfor merupakan mineral kedua terbanyak dalam tubuh, yaitu sekitar 1\%. Fosfor berperan dalam pembentukan tulang dan gigi, penyimpanan dan pengeluaran energi (perubahan ATP dengan ADP). Sebagian besar subjek dari kedua kelompok (demensia dan tidak demensia) memiliki tingkat kecukupan fosfor yang tergolong cukup, yaitu $\geq 77 \%$ AKG fosfor harian. Tingkat kecukupan fosfor yang cukup berkaitan dengan rata-rata asupan fosfor untuk kedua kelompok subjek yang tergolong cukup, dimana untuk subjek yang tidak demensia sekitar 866.4 \pm SD mg dan sekitar 637.6 mg untuk subjek yang demensia.

Besi merupakan mineral mikro yang paling banyak terdapat dalam tubuh, yaitu sebanyak 3-5 g. Besi memiliki beberapa fungsi esensial dalam tubuh seperti alat angkut oksigen dari paru-paru ke jaringan tubuh, sebagai alat angkut elektron dalam sel, dan sebagai bagian dari berbagai reaksi enzim dalam jaringan tubuh. Sebagian besar subjek dari kedua kelompok memiliki tingkat kecukupan besi yang cukup, yaitu $\geq 77 \%$ AKG besi harian. Hal ini berkaitan dengan banyaknya subjek yang mengonsumsi pangan yang banyak mengandung Fe seperti susu, ikan, ayam, dan bayam. Sumber besi yang baik adalah dari makanan hewani seperti daging, ayam, telur, dan ikan. Sumber besi yang lainnya yaitu serealia, kacang-kacangan, sayuran hijau, dan beberapa jenis buah. Daya absorpsi besi berbeda untuk bahan pangan satu dengan lainnya. Rata-rata asupan besi untuk kedua kelompok subjek yang tergolong cukup, dimana untuk subjek tidak demensia sekitar $16.1 \mathrm{mg}$ dan sekitar $15.2 \mathrm{mg}$ untuk subjek demensia. 


\section{Aktivitas Fisik}

Subjek yang sudah mengalami demensia sebagian besar hanya duduk-duduk dan tidur sepanjang hari serta tidak melakukan aktivitas fisik apapun. Subjek yang tidak mengalami demensia sebagian besar masih aktif (55.6\%). Subjek yang tidak mengalami demensia masih melakukan aktivitas fisik secara normal. Subjek masih mengikuti senam lansia, jalan-jalan sekeliling panti, dan mengerjakan pekerjaan rumah secara mandiri, sehingga nilai PAL yang didapat masih tergolong aktif. Aktivitas fisik yang baik mampu meningkatkan aliran oksigen ke otak. Otak membutuhkan oksigen untuk oksidasi glukosa dalam produksi energi listrik yang memicu ingatan kita. Otak hanya menyumbang $2 \%$ dari berat tubuh tetapi kebutuhan akan oksigen sangat besar yaitu sekitar 20\% dari berat tubuh.

\section{Keadaan Kognitif Subjek}

Demensia dapat diartikan sebagai gangguan kognitif dan memori yang dapat memengaruhi aktivitas sehari-hari. CDR menggambarkan lima tingkatan demensia dalam enam faktor yaitu daya ingat, orientasi, penilaian dan pemecahan masalah, kehidupan bermasyarakat, hobi dan rumah tangga, dan perawatan diri. Distribusi subjek berdasarkan hasil pengukuran keadaan kognitif subjek dengan CDR (Clinical Dementia Rating) pada seluruh subjek dapat dilihat pada Tabel 1.

Tabel 1 menunjukkan faktor pertama yaitu daya ingat. Sebagian besar lansia memiliki skor CDR sebesar 0.5 dengan persentase $33.3 \%$. Skor 0.5 dalam faktor daya ingat memiliki arti bahwa lansia sering lupa akan hal tertentu namun terbatas (belum terlalu banyak). Faktor kedua yaitu orientasi, diketahui sebagian besar lansia memiliki skor CDR 0.5 dengan persentase $31 \%$. Skor 0.5 dalam orientasi menunjukkan bahwa lansia berorientasi penuh kecuali yang berhubungan dengan waktu. Faktor ketiga yaitu penilaian dan pemecahan masalah, diketahui sebagian besar lansia memiliki skor CDR 0.5 dengan persentase $33.3 \%$. Skor 0.5 dalam penilaian dan pemecahan masalah berarti lansia mengalami sedikit ketidakmampuan untuk memecahkan masalah dan dalam hal menentukan persamaan dan perbedaan juga mengalami kesulitan. Faktor keempat yaitu kehidupan bermasyarakat. Sebagian besar lansia memiliki skor CDR 0 dengan persentase 33.3\%. Skor 0 dalam kehidupan bermasyarakat berarti lansia masih mampu secara mandiri untuk menjalankan kegiatan hariannya seperti berbelanja, bekerja, serta menjadi sukarelawan dalam kelompok sosial. Faktor kelima yaitu hobi dan rumah tangga, diketahui sebagian besar lansia memiliki skor CDR 3 dengan persentase $33.3 \%$. Skor 3 dalam hobi dan rumah tangga berarti lansia sudah mampu mengerjakan pekerjaan rumah apapun. Hal ini berkaitan dengan terganggunya fungsi kognitif serta keterbatasan fisik
Tabel 1. Distribusi Subjek berdasarkan Hasil Pengukuran Keadaan Kognitif Subjek dengan CDR (Clinical Dementia Rating)

\begin{tabular}{|c|c|c|c|}
\hline \multirow{2}{*}{ Aspek } & \multirow{2}{*}{ CDR } & \multicolumn{2}{|c|}{ Jumlah dan Persentase } \\
\hline & & $n$ & $\%$ \\
\hline \multirow{5}{*}{ Daya Ingat } & 0 & 5 & 11.9 \\
\hline & 0.5 & 14 & 33.3 \\
\hline & 1 & 7 & 16.7 \\
\hline & 2 & 7 & 16.7 \\
\hline & 3 & 9 & 21.4 \\
\hline \multirow{5}{*}{ Orientasi } & 0 & 9 & 21.4 \\
\hline & 0.5 & 13 & 31.0 \\
\hline & 1 & 6 & 14.3 \\
\hline & 2 & 5 & 11.9 \\
\hline & 3 & 9 & 21.4 \\
\hline \multirow{5}{*}{$\begin{array}{l}\text { Penilaian dan } \\
\text { Pemecahan } \\
\text { Masalah }\end{array}$} & 0 & 8 & 19.0 \\
\hline & 0.5 & 14 & 33.3 \\
\hline & 1 & 4 & 9.5 \\
\hline & 2 & 5 & 11.9 \\
\hline & 3 & 11 & 26.2 \\
\hline \multirow{5}{*}{$\begin{array}{c}\text { Kehidupan } \\
\text { Bermasyarakat }\end{array}$} & 0 & 14 & 33.3 \\
\hline & 0.5 & 6 & 14.3 \\
\hline & 1 & 9 & 21.4 \\
\hline & 2 & 1 & 2.4 \\
\hline & 3 & 12 & 28.6 \\
\hline \multirow{5}{*}{$\begin{array}{l}\text { Hobi dan Rumah } \\
\text { tangga }\end{array}$} & 0 & 8 & 19.0 \\
\hline & 0.5 & 9 & 21.4 \\
\hline & 1 & 6 & 14.3 \\
\hline & 2 & 5 & 11.9 \\
\hline & 3 & 14 & 33.3 \\
\hline \multirow{5}{*}{ Perawatan Diri } & 0 & 13 & 31.0 \\
\hline & 0.5 & 3 & 7.1 \\
\hline & 1 & 15 & 35.7 \\
\hline & 2 & 1 & 2.4 \\
\hline & 3 & 10 & 23.8 \\
\hline
\end{tabular}

yang dialami lansia. Faktor keenam yaitu perawatan diri. Sebagian besar lansia memiliki skor CDR 1 dengan persentase $35.7 \%$. Skor 1 dalam perawatan diri berarti lansia membutuhkan sedikit bantuan untuk perawatan dirinya. Hal ini terkait dengan terganggunya fungsi kognitif serta keterbatasan fisik yang dialami lansia.

\section{Riwayat Demensia Keluarga}

Sebagian besar subjek yang demensia tidak diketahui riwayat demensia keluarganya (50.0\%). Sebesar $25.0 \%$ subjek demensia diketahui tidak ada riwayat keluarga demensia dan ada riwayat keluarga demensia. Subjek tidak demensia sebagian besar tidak ada riwayat keluarga yang demensia (72.2\%). 


\section{Riwayat Penyakit}

Riwayat penyakit yang menjadi fokus dalam penelitian ini adalah hipertensi, diabetes mellitus, dan stroke. Berdasarkan hasil wawancara pada subjek diketahui sebagian besar subjek tidak ada riwayat penyakit tersebut. Diketahui sebesar $66.7 \%$ subjek yang demensia tidak ada riwayat penyakit dan sebesar $38.9 \%$ subjek yang tidak demensia tidak ada riwayat penyakit (Tabel 2).

Tabel 2. Sebaran Subjek berdasarkan Riwayat Penyakit

\begin{tabular}{lcccc}
\hline \multirow{2}{*}{ Riwayat Penyakit } & \multicolumn{2}{c}{ Demensia } & \multicolumn{2}{c}{$\begin{array}{c}\text { Tidak } \\
\text { Demensia }\end{array}$} \\
\cline { 2 - 5 } & $\mathrm{n}$ & $\%$ & $\mathrm{n}$ & $\%$ \\
\hline Tidak ada riwayat penyakit & 16 & 66.7 & 7 & 38.9 \\
Hipertensi & 6 & 25.0 & 5 & 27.8 \\
Diabetes mellitus & 0 & 0.0 & 4 & 22.2 \\
Hipertensi \& & 0 & 0.0 & 1 & 5.6 \\
diabetes mellitus & 2 & 8.3 & 1 & 5.6 \\
Hipertensi \& stroke & &
\end{tabular}

Hubungan Karakteristik Subjek dengan Kejadian Demensia

Hasil uji korelasi antara usia subjek dengan kejadian demensia menunjukkan bahwa tidak terdapat hubungan yang signifikan ( $p>0.05$ ). Hasil tersebut sejalan dengan penelitian yang dilakukan Tani dan kawan-kawan tahun 2007. Penelitian tersebut menunjukkan hubungan yang tidak signifikan antara usia dengan kerusakan kognitif pada subjek. Namun terlihat adanya kecenderungan positif yang berarti bahwa semakin tua usia subjek maka semakin tinggi pula nilai CDR.

Hasil korelasi antara tingkat pendidikan dengan kejadian demensia menunjukkan hubungan negatif signifikan $(p<0.05)$. Hal ini sejalan dengan Richard et al. (2007) yang menyebutkan bahwa subjek dengan pendidikan di bawah 8 tahun mengalami kejadian demensia 2.6 kali lebih besar dibanding subjek dengan pendidikan di atas 8 tahun.

Hubungan Tingkat Kecukupan Vitamin A, B1, B2, B6, Asam Folat, dan Vitamin C dengan Kejadian Demensia

Hasil uji korelasi antara tingkat kecukupan vitamin A dengan kejadian demensia menunjukkan hubungan negatif signifikan $(p<0.05)$. Hal ini berarti semakin rendah tingkat kecukupan vitamin A maka semakin tinggi nilai CDR. Nilai CDR yang semakin tinggi menunjukkan semakin buruknya kondisi kognitif seorang subjek. Menurut Goodman (2006), kadar vitamin A di otak menurun seiring dengan bertambahnya usia dan semakin rendah pada orang yang menderita demensia.

Hasil uji korelasi antara tingkat kecukupan vitamin B1, B2, dan B6 dengan kejadian demensia menunjukkan bahwa terdapat hubungan negatif yang signifikan antara tingkat kecukupan vitamin $B 1, B 2$, dan B6 dengan kejadian demensia $(p<0.05)$. Hal ini berarti semakin rendah tingkat kecukupan vitamin B1, B2, dan B6 maka semakin tinggi nilai CDR. Beberapa studi telah menunjukkan bahwa terdapat hubungan antara kekurangan vitamin $B$ dengan gangguan metabolik pada penyusun struktural jaringan otak, seperti phospholipids dan myelin, serta sinyal molekul, seperti neurotransmitter (Koseoglu 2011).

Hasil uji korelasi antara tingkat kecukupan asam folat dengan kejadian demensia menunjukkan tidak terdapat hubungan yang signifikan antara tingkat kecukupan asam folat dengan kejadian demensia ( $p>0.05)$. Namun uji korelasi tersebut menunjukkan adanya kecenderungan negatif yang berarti bahwa semakin rendah tingkat kecukupan asam folat maka semakin tinggi nilai CDR. Menurut Morris et al. dan Fridman (2005), terdapat hubungan antara asupan asam folat dengan fungsi kognitif.

Hasil uji korelasi antara tingkat kecukupan vitamin $\mathrm{C}$ dengan kejadian demensia menunjukkan terdapat hubungan negatif yang signifikan antara tingkat kecukupan vitamin $C$ dengan kejadian demensia $(p<0.05)$, yang berarti bahwa semakin rendah tingkat kecukupan vitamin C maka semakin tinggi nilai CDR. Studi Engelhart et al. (2003), konsumsi tinggi vitamin $\mathrm{C}$ diketahui terkait dengan risiko lebih rendah terhadap demensia.

\section{Hubungan Aktivitas Fisik dengan Kejadian Demen- sia}

Hasil uji korelasi antara aktivitas fisik dengan kejadian demensia menunjukkan terdapat hubungan negatif yang signifikan $(p<0.05)$. Semakin tinggi tingkat aktivitas subjek maka semakin rendah nilai CDR. Hasil tersebut sejalan dengan penelitian yang dilakukan di Kanada untuk 9008 subjek berusia di atas 65 tahun. Penelitian yang dilakukan oleh Lewerin (2005) menunjukkan adanya hubungan yang signifikan antara subjek yang memiliki aktivitas fisik dan yang tanpa aktivitas fisik dengan kejadian demensia.

\section{Hubungan Riwayat Demensia Keluarga dan Ri- wayat Penyakit dengan Kejadian Demensia}

Hasil uji korelasi antara riwayat demensia keluarga dengan kejadian demensia menunjukkan tidak terdapat hubungan yang signifikan ( $p>0.05)$. Namun terdapat kecenderungan positif yang berarti bahwa dengan adanya orangtua subjek yang menderita demensia maka semakin tinggi nilai CDR. Hal ini diduga karena adanya 33.3\% dari keseluruhan lansia yang menjadi subjek tidak diketahui ada atau tidaknya riwayat demensia keluarganya.

Hasil uji korelasi antara riwayat penyakit hipertensi dengan kejadian demensia menunjuk- 
kan bahwa tidak terdapat hubungan yang signifikan ( $p>0.05)$. Namun hasil uji korelasi tersebut juga menunjukkan adanya kecenderungan positif yang berarti bahwa dengan adanya hipertensi pada subjek maka semakin tinggi nilai CDR.

Hasil uji korelasi antara riwayat penyakit diabetes mellitus dengan kejadian demensia menunjukkan bahwa terdapat hubungan positif yang signifikan $(p<0.05)$, hal ini berarti bahwa dengan adanya diabetes mellitus pada subjek maka semakin tinggi nilai CDR. Menurut Richard et al. (2007), diabetes mellitus merupakan faktor risiko untuk terjadinya demensia pada subjek.

\section{Faktor-faktor yang Memengaruhi Kejadian De- mensia}

Faktor-faktor yang berhubungan signifikan dengan kejadian demensia diantaranya tingkat kecukupan vitamin A (X1), vitamin B1 (X2), vitamin B2 (X3), vitamin B6 (X4), vitamin C (X5), riwayat penyakit diabetes mellitus (X6), aktivitas fisik (X7), dan tingkat pendidikan (X8). Berdasarkan hasil uji regresi logistik, diketahui hanya aktivitas fisik yang memiliki pengaruh signifikan terhadap kejadian demensia pada lansia sedangkan faktor lain hanya berhubungan signifikan namun tidak berpengaruh. Semakin tinggi level aktivitas fisik maka semakin rendah kejadian demensia pada lansia di panti Werdha Tresna.

\section{KESIMPULAN}

Frekuensi makan sebagian besar subjek adalah 3 kali sehari dengan nasi sebagai pangan sumber karbohidratnya. Pangan sumber hewani yang banyak dikonsumsi adalah telur ayam, sedangkan pangan nabati yang biasa dikonsumsi adalah tahu dan tempe. Sayuran yang banyak dikonsumsi adalah wortel dan kol. Buah-buahan yang biasa dikonsumsi adalah pepaya dan pisang.

Tingkat kecukupan energi sebagian besar subjek yang demensia tergolong lebih, dan untuk subjek yang tidak demensia tergolong normal atau cukup. Tingkat kecukupan protein sebagian besar subjek yang demensia tergolong defisit berat, sedangkan subjek yang tidak demensia tergolong cukup. Seluruh subjek memiliki tingkat kecukupan vitamin A yang cukup. Tingkat kecukupan vitamin B1, vitamin B2, asam folat sebagian besar subjek dari kedua kelompok tergolong defisit (<77\% AKG harian). Tingkat kecukupan vitamin B6 dan vitamin $\mathrm{C}$ sebagian besar subjek yang demensia tergolong defisit (<77\% AKG harian), dan untuk subjek yang tidak demensia tergolong cukup ( $\geq 77 \%$ AKG harian). Tingkat kecukupan fosfor dan besi sebagian besar subjek dari kedua kelompok tergolong cukup ( $\geq 77 \%$ AKG harian).

Sebagian besar subjek yang demensia sudah tidak aktif (66.7\%), dan subjek yang tidak demensia sebagian besar masih aktif (55.6\%). Sebagian besar subjek dari kedua kelompok tidak ada riwayat penyakit. Sebagian subjek yang demensia tidak diketahui riwayat demensia keluarganya (50.0\%) dan sebagian besar subjek yang tidak demensia tidak ada riwayat demensia keluarga (72.2\%). Terdapat hubungan yang signifikan antara tingkat kecukupan vitamin A, vitamin B1, vitamin B2, vitamin B6, vitamin C, tingkat pendidikan, riwayat diabetes mellitus, dan aktivitas fisik dengan kejadian demensia. Berdasarkan uji regresi logistik yang berpengaruh terhadap kejadian demensia adalah aktivitas fisik.

Panti sebaiknya memerhatikan aktivitas fisik harian subjek agar kesehatan subjek tetap terjaga. Aktivitas fisik yang cukup mampu meningkatkan aliran oksigen ke otak sehingga daya ingat subjek tetap terjaga. Selain itu perlu diperhatikan juga keberagaman pangan subjek. Diperlukan adanya ahli gizi untuk mengatur pola makan subjek agar tingkat kecukupan zat gizi harian subjek baik zat gizi mikro maupun zat gizi makro terpenuhi dengan baik.

\section{DAFTAR PUSTAKA}

Arisman. 2004. Buku Ajar Ilmu Gizi: Gizi dalam Daur Kehidupan. EGC, Jakarta.

Das UN. 2008. Folic acid and polyunsaturated fatty acids improve cognitive function and prevent depression, dementia, and Alzheimer's disease-but how and why? Prostaglandins Leukot Essent Fatty Acids, 78(1), 11-20.

Engelhart MJ, Geerlings MI, Ruitenberg A, van Switen JC, Hofman A, Witteman JC \& Breteler MM. 2003. Dietary intake of antioxidants and risk of Alzheimer disease. JAMA, 287(24), 32233232.

Fridman S. 2005. High folic acid intake is not a risk factor for cognitive decline: misinterpretation of results. Arch Neurol, 62, 1786-1793.

Goodman AB. 2006. Retinoid receptors, transporters, and metabolizers as therapeutic targets in late onset Alzheimer disease. J Cell Physiol, 209(3), 598-603.

Gray SL, Anderson ML, Crane PK, Breitner JC, McCormick W, Bowen JD, Teri L, \& Larson E. 2008. Antioxidant vitamin supplement use and risk of dementia or Alzheimer's disease in older adults. J Am Geriatr Soc, 56(2), 291-96.

Hsu \& Yi-Hsiang et al. 2006. Relation of body compotition, fat mass, serum lipids to osteoporosis fractures and bone mineral density in Chinese men and women. Am J Clin Nutr, 83, 146-154.

Koseoglu E. 2011. Alzheimer's Disease PathogenesisCore Concepts, Shifting Paradigms and Therapeutic Targets. Erciyes University, Medicine Faculty, Neurology Department, Kayseri, Turkey : In Tech http://ebookee.org/Alzheimer- 
Pratiwi dkk.

s-Disease-Pathogenesis-CoreConcepts ShiftingParadigms-and TherapeuticTargets_1373966. pdf [diakses 10 Mei 2013].

Lewerin C, Matousek M, Steen G, Johansson B, Steen B, \& Nilsson-Ehle H. 2005. Significant correlations of plasma homocysteine and serum methylmalonic acid with movement and cognitive performance in elderly subjects but no improvement from short-term vitamin therapy: a placebo-controlled randomized study. Am J Clin Nutr, 81(5), 1155-62.

Morris MC, Evans DA, Bienias JL, Tangney CC, Hebert LE, \& Scherr PA. 2005. Dietary folate and vi- tamin B12 intake and cognitive decline among community-dwelling older persons. Arch Neurol, 62, 641-646.

OTA. 1987. Confronting Alzheimer's Disease and Other Dementias. Science Information Resource Center, Washington DC.

Richard JH, Solane PD, Warshaw GA, Bernard MA, \& Flaherty E. 2007. Primary care geriatrics- a case based approach. Elsevier, 5,156-164.

Tani J. 2008. Dietary vitamins B, folic acid and cognitive impairment in the elderly. Maj Kedokteran Indonesia, 58(3), 68-72. 